\title{
The Math Gender Gap: The Role of Culture ${ }^{\dagger}$
}

\author{
By Natalia Nollenberger, Núria Rodríguez-Planas, and Almudena Sevilla*
}

Using analysis across countries or states, previous studies show that girls in more gender-equal countries or states perform relatively better than boys in math test scores (Guiso et al. 2008; Fryer and Levitt 2010; Pope and Sydnor 2010). While it is possible that greater gender equality leads to a reduction in the math gender gap, an alternative interpretation of these findings could be that in countries where girls perform relatively better at math, women might also be more prepared, access better jobs, earn higher wages, and be more easily promoted and politically empowered-leading to greater gender equality.

The current paper's contribution to this literature is twofold. First, we assess the direction of causality using the epidemiological approach (Fernández 2011). Second, we quantify the effect of values and beliefs about women's role in society transmitted from generation to generation (what we call "culture on gender equality") versus that of a country's institutions and formal practices on the math gender gap. In doing so, we inform a public policy issue of first-order importance.

The epidemiological approach focuses on second-generation immigrants, who have lived in a host country since birth and are exposed to the same host-country institutions. Crucially, second-generation immigrants living in the

\footnotetext{
* Nollenberger: IE Business School, IE University, Calle de María de Molina, 11-15, 28006 Madrid, Spain (e-mail: nnollenberger@gmail.com); Rodríguez-Planas: Economic Department, City University of New York (CUNY), Queens College, Powdermaker Hall, 65-30 Kissena Boulevard, Queens, NY 11367 (e-mail: nuria.rodriguezplanas@ qc.cuny. edu); Sevilla: School of Business and Management, Queen Mary, University of London, Francis Bancroft Building, Mile End Road, London E1 4NS (e-mail: a.sevilla@qmul. ac.uk). Corresponding author: Rodríguez-Planas. The authors declare that they have no relevant or material financial interests that relate to the research described in his paper.

$\dagger$ Go to http://dx.doi.org/10.1257/aer.p20161121 to visit the article page for additional materials and author disclosure statement $(\mathrm{s})$.
}

same host country are also likely to be influenced by the cultural beliefs of their parents' ancestry country. Given that math test scores of second-generation immigrants are unlikely to affect gender-equality measures (culture or institutions) of their parents' country of ancestry, the problem of reverse causality is less of an issue in our paper. In addition, with the epidemiological approach, any country-of-ancestry variation in the math gender gap of second-generation immigrants in a particular host country can only be attributed to cultural differences transmitted from the immigrants' parents (or peers), as opposed to institutional differences.

\section{Data}

We use data from the 2003, 2006, 2009, and 2012 Program for International Student Assessment (PISA), which contains a standardized (and, hence, culture-neutral) mathematics assessment administered to 15 -year-olds in schools. Our sample contains 11,527 second-generation migrants from 35 different countries of ancestry and living in 9 host countries (see online Appendix Table A.1).

On average, the gender gap in math scores (defined as the difference in math score between girls and boys) among second-generation immigrants is 15.70 , equivalent to 4.5 months of schooling (see online Appendix Table A.2). Crucially, it varies widely by country of ancestry. Whereas at the bottom 10 percent of the distribution second-generation immigrant girls underperform boys by as much as 63 score points (equivalent to a difference of almost 1.5 years of schooling), at the top 10 percent of the distribution, second-generation immigrant girls outperform boys by around 36 points (a difference equivalent to 10 months of schooling).

Following Guiso et al. (2008), we use the 2009 Gender Gap Index-henceforth, GGIin the country of ancestry from the World Economic Forum to measure gender equality in an immigrant's country of ancestry. The GGI 
measures economic and political opportunities, education, and well-being for women, and ranges from 0 to 1 , with larger values pointing to a better position of women in society.

Figure 1 plots the average math gender gap of second-generation immigrants by country of ancestry (column 1 in online Appendix Table A.2) versus the GGI (column 2 in online Appendix Table A.2). Overall, the raw data show that the more gender equality in the country of ancestry, the higher the math scores of second-generation immigrant girls relative to boys. The correlation is 0.22 percent and is statistically significant.

\section{Empirical Methodology}

To estimate the effect of cultural attitudes toward gender equality on the math gender gap, we run the following model:

$$
\begin{aligned}
E_{i j k t}= & \alpha_{1} \text { female }_{i}+\alpha_{2}\left(\text { female }_{i} G G I_{j}\right) \\
& +X_{i j k t}^{\prime} \beta_{1}+\left(X_{i j k t}^{\prime} \text { female }_{i}\right) \beta_{2}+\lambda_{j} \\
& +\lambda_{k}+\lambda_{t}+\delta\left(\text { female }_{i} \lambda_{k}\right)+\varepsilon_{i j k t},
\end{aligned}
$$

where $E_{i j k t}$ is the math test score of individual $i$ who lives in country $k$ at time $t$ and is of ancestry $j$. female $e_{i}$ is an indicator equal to one if the individual is a girl and zero otherwise. $G G I_{j}$ measures gender equality from the immigrant $i$ 's country of ancestry $j$. $X_{i j k t}$ is a set of individual characteristics which varies depending on the specification considered. The construction of all individual variables and basic summary statistics are shown in online Appendix Table A.3. We also include a full set of dummies that control for the country of ancestry $j\left(\lambda_{j}\right)$, host country $\left(\lambda_{k}\right)$, and the PISA cohort $t\left(\lambda_{t}\right)$. Country-of-ancestry fixed effects $\left(\lambda_{j}\right)$ control for the GGI in the country of ancestry and for any other country-of-ancestry factors that affect the math scores of boys and girls in the same way. Host-country dummies $\left(\lambda_{k}\right)$ are interacted with the female dummy to account for variation in the host-country educational gender gaps that may arise from across host-country differentials in cultural or institutional channels.

The coefficient of interest is the coefficient on the interaction between the GGI and the female indicator, $\alpha_{2}$, which captures the role of culture on gender equality in explaining the

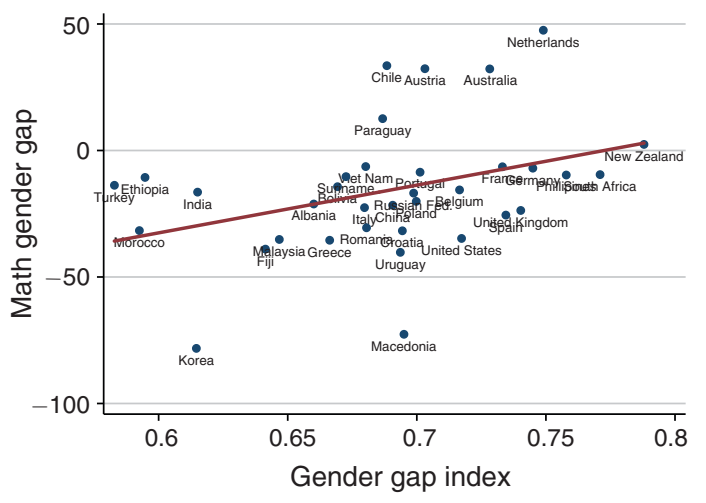

Figure 1. Gender Math Test Scores of SecondGeneration Immigrants and Gender EQuality in Their COUNTRY OF ANCESTRY

Notes: Figure 1 displays the correlation between the raw average math gender gap among second-generation immigrants and the GGI in the country of ancestry. The math gender gap was obtained from estimating a linear regression using the plausible values provided by the PISA datasets as left-hand-side variable and a female indicator as right-handside variable. We estimated one regression for each plausible value for each country and present the average of the five coefficients estimated. We use individuals with both parents who were born in a foreign country from the 2003, 2006, 2009, and 2012 PISA datasets.

gender differences in the math test scores of second-generation immigrant girls relative to boys. A positive and significant $\alpha_{2}$ would suggest that more gender-equal cultural norms toward the role of women in society are associated with a higher relative math performance of second-generation-immigrant girls over boys.

\section{Results}

Our baseline specification (column 1 in Table 1) includes as individual controls the age of the child at the time of the exam and a dummy indicating whether the individual is in a different grade from the modal grade in the host country. The coefficient of interest, $\alpha_{2}$, is positive and statistically significant, indicating that the math gender gap decreases for immigrants whose parents come from more gender-equal countries. Given that immigrants are not necessarily representative of their country of ancestry's population and are, probably, less likely to be influenced by their country of ancestry's culture, the fact that we find that culture of ancestry matters is remarkable. Results remain robust to 
a battery of sensitivity checks as shown in online Appendix Tables A.4 and A.5 .

Column 2 in Table 1 shows our preferred specification, which includes the real log GDP per capita in the country of ancestry interacted with the female indicator in order to capture differences in the country of ancestry's culture beyond those due to differences in the economic development, which may affect an immigrant's test scores for reasons unrelated to gender-equality norms in their country of ancestry. We find that a one standard deviation increase in the gender equality index is associated with a reduction of 7.47 score points in the math gender gap (about one and a half months of schooling). A reduction of 7.47 points represents 29 percent of the standard deviation in the math gender gap across countries of ancestry. ${ }^{1}$

Column 3 in Table 1 shows that results remain qualitatively the same under an alternative specification to equation (1) that excludes the country-of-ancestry fixed effects and instead adds first-order effects of the GGI (and also the GDP) in the country of ancestry.

To address concerns that several sources of heterogeneity across individuals other than cultural beliefs on gender roles may affect their educational attainment, in column 4 we add to the preferred specification parent's highest education level and its interaction with the female indicator. If less educated parents (who may happen to come from less gender-equal countries) invest relatively less in their girls' than in their boys' education than more educated parents (who may happen to come from more gender-equal countries), failure to control for parental education (and their interaction with the female indicator) may lead us to incorrectly conclude that cultural beliefs are affecting the math gender gap. Having higher educated parents increases math test scores, albeit not differentially for boys than for girls. More importantly, the effect of culture on the math gender gap continues to be positive and statistically significant.

One concern with the above estimates is that all individuals may have the same biased gender attitudes independently of country of ancestry but that, according to how credit constrained

\footnotetext{
${ }^{1}$ Using estimates from column 2 in Table 1, these values are calculated as follows: $\alpha_{2}(149.55) \times G G I_{\text {std }}(0.05)$ $=7.47$, and $\frac{7.47}{\text { Gender Gap in Math } \text { std }_{\text {(26.04) }}}=0.29$.
}

they are, they invest more or less in their girls. As parental income is unavailable in our dataset, column 5 in Table 1 controls instead for two indicator variables taking value one if the mother (or father) works, as well as for an index of family (material and educational) resources, and their interaction with the female indicator. Whereas more family resources seem to benefit girls more than boys, the opposite is true for having a working mother (albeit these coefficients are only statistically significant at the 10 percent level). Compared to results in column 2 , our coefficient of interest increases in magnitude, suggesting that our measure of culture was picking up the differential negative effect that these variables have on girls relative to boys.

Another concern is that girls from more gender-equal countries may also attend schools where they perform better relative to boys. To the extent that girls from more gender-equal countries are less likely to be discriminated against by teachers, either because they attend schools with more female teachers or schools with a higher proportion of teachers from their same ethnicity (Dee 2005), they may do relatively better (with respect to boys) than girls from less gender-equal countries. Gneezy, Niederle, and Rustichini (2003) show that a higher proportion of girls in schools may boost women's confidence and, subsequently, improve their math performance relative to boys. Thus, an alternative reason why girls from more gender-equal countries may do relatively better (with respect to boys) than girls from less gender-equal countries could be that they attend schools where there is a higher proportion of girls. Column 6 accounts for these factors by adding to the specification in column 5 the percentage of girls enrolled at school, as well as other school characteristics, and the interaction between these variables and the female indicator. Our coefficient of interest remains similar in magnitude to our earlier estimates.

\section{Conclusion}

Below, we quantify how much cultural beliefs on the role of women in society matter vis-à-vis other gender-equal societal factors. To do so, we compare the magnitudes of the estimates from the epidemiological approach in equation (1) to those from a model estimated on both natives and immigrants, where the country-of-ancestry GGI 
Table 1- Gender Equality and the Math Gender Gap

\begin{tabular}{|c|c|c|c|c|c|c|}
\hline & (1) & $(2)$ & (3) & (4) & $(5)$ & (6) \\
\hline Female & $\begin{array}{l}-191.32 \\
{[294.86]}\end{array}$ & $\begin{array}{c}-177.15 \\
{[279.74]}\end{array}$ & $\begin{array}{l}-104.61 \\
{[204.83]}\end{array}$ & $\begin{array}{c}-198.47 \\
{[304.58]}\end{array}$ & $\begin{array}{l}-173.27 \\
{[276.15]}\end{array}$ & $\begin{array}{c}-185.23 \\
{[289.12]}\end{array}$ \\
\hline GGI $\times$ Female & $\begin{array}{l}110.53^{* *} \\
{[51.08]}\end{array}$ & $\begin{array}{l}149.55^{* *} \\
{[62.62]}\end{array}$ & $\begin{array}{l}139.35^{* *} \\
{[63.46]}\end{array}$ & $\begin{array}{l}155.51 * * * \\
{[60.08]}\end{array}$ & $\begin{array}{l}170.83^{* * * *} \\
{[60.98]}\end{array}$ & $\begin{array}{l}156.31 * * \\
{[61.13]}\end{array}$ \\
\hline Age of student & $\begin{array}{c}7.77 \\
{[6.73]}\end{array}$ & $\begin{array}{c}7.90 \\
{[6.71]}\end{array}$ & $\begin{array}{c}9.46 \\
{[6.76]}\end{array}$ & $\begin{array}{c}7.53 \\
{[6.81]}\end{array}$ & $\begin{array}{c}8.61 \\
{[6.80]}\end{array}$ & $\begin{array}{l}8.15 \\
{[6.90]}\end{array}$ \\
\hline Age $\times$ Female & $\begin{array}{c}6.22 \\
{[9.55]}\end{array}$ & $\begin{array}{c}6.07 \\
{[9.54]}\end{array}$ & $\begin{array}{c}2.29 \\
{[9.73]}\end{array}$ & $\begin{array}{c}7.21 \\
{[9.56]}\end{array}$ & $\begin{array}{c}6.82 \\
{[9.47]}\end{array}$ & $\begin{array}{c}6.20 \\
{[9.60]}\end{array}$ \\
\hline Diff. grade & $\begin{array}{l}-13.69 * * * \\
{[4.69]}\end{array}$ & $\begin{array}{l}-13.82 * * * \\
{[4.69]}\end{array}$ & $\begin{array}{c}-16.69 * * * \\
{[4.91]}\end{array}$ & $\begin{array}{l}-13.63 * * * \\
{[4.86]}\end{array}$ & $\begin{array}{c}-12.56 * * * \\
{[4.79]}\end{array}$ & $\begin{array}{c}-12.35^{* *} \\
{[4.83]}\end{array}$ \\
\hline Diff. grade $\times$ Female & $\begin{array}{c}-5.94 \\
{[6.29]}\end{array}$ & $\begin{array}{c}-5.64 \\
{[6.30]}\end{array}$ & $\begin{array}{r}-6.32 \\
{[6.77]}\end{array}$ & $\begin{array}{c}-3.73 \\
{[6.36]}\end{array}$ & $\begin{array}{l}-3.14 \\
{[6.25]}\end{array}$ & $\begin{array}{c}-3.04 \\
{[6.10]}\end{array}$ \\
\hline GDP $\times$ Female & & $\begin{array}{c}-3.94 \\
{[3.30]}\end{array}$ & $\begin{array}{r}-4.40 \\
{[3.67]}\end{array}$ & $\begin{array}{c}-3.60 \\
{[3.28]}\end{array}$ & $\begin{array}{c}-4.57 \\
{[3.38]}\end{array}$ & $\begin{array}{c}-4.28 \\
{[3.34]}\end{array}$ \\
\hline Dad educ. & & & & $\begin{array}{l}6.85 * * * \\
{[1.52]}\end{array}$ & $\begin{array}{l}5.62 * * * \\
{[1.52]}\end{array}$ & $\begin{array}{l}5.42 * * * \\
{[1.51]}\end{array}$ \\
\hline Dad educ. $\times$ Female & & & & $\begin{array}{c}-1.12 \\
{[2.06]}\end{array}$ & $\begin{array}{c}-1.53 \\
{[2.09]}\end{array}$ & $\begin{array}{c}-1.56 \\
{[2.08]}\end{array}$ \\
\hline Mom educ. & & & & $\begin{array}{l}4.14 * * * \\
{[1.44]}\end{array}$ & $\begin{array}{l}2.93 * * \\
{[1.46]}\end{array}$ & $\begin{array}{c}2.69^{*} \\
{[1.44]}\end{array}$ \\
\hline Mom educ. $\times$ Female & & & & $\begin{array}{c}-0.54 \\
{[1.73]}\end{array}$ & $\begin{array}{c}-0.62 \\
{[1.81]}\end{array}$ & $\begin{array}{c}-0.49 \\
{[1.79]}\end{array}$ \\
\hline Dad work & & & & & $\begin{array}{l}20.15 * * * \\
{[7.09]}\end{array}$ & $\begin{array}{l}19.92 * * * \\
{[6.97]}\end{array}$ \\
\hline Dad work $\times$ Female & & & & & $\begin{array}{l}-9.32 \\
{[9.23]}\end{array}$ & $\begin{array}{l}-9.17 \\
{[9.20]}\end{array}$ \\
\hline Mom work & & & & & $\begin{array}{l}17.01 * * * \\
{[4.89]}\end{array}$ & $\begin{array}{l}15.93 * * * \\
{[4.94]}\end{array}$ \\
\hline Mom work $\times$ Female & & & & & $\begin{array}{c}-12.92^{*} \\
{[7.58]}\end{array}$ & $\begin{array}{r}-11.05 \\
{[7.52]}\end{array}$ \\
\hline Home possessions & & & & & $\begin{array}{l}11.10 * * * \\
{[2.57]}\end{array}$ & $\begin{array}{l}11.20^{* * * *} \\
{[2.49]}\end{array}$ \\
\hline $\begin{array}{l}\text { Home possessions } \\
\quad \times \text { Female }\end{array}$ & & & & & $\begin{array}{c}6.14^{*} \\
{[3.46]}\end{array}$ & $\begin{array}{c}5.92^{*} \\
{[3.37]}\end{array}$ \\
\hline $\begin{array}{l}\text { Proportion of girls } \\
\text { at school }\end{array}$ & & & & & & $\begin{array}{c}-18.07 \\
{[13.77]}\end{array}$ \\
\hline Prop. girls $\times$ Female & & & & & & $\begin{array}{l}47.34 * * * \\
{[18.35]}\end{array}$ \\
\hline Private school & & & & & & $\begin{array}{c}6.91 \\
{[7.79]}\end{array}$ \\
\hline Private school $\times$ Female & & & & & & $\begin{array}{c}2.90 \\
{[7.93]}\end{array}$ \\
\hline School is in a metropolis & & & & & & $\begin{array}{l}18.12^{* * * *} \\
{[5.75]}\end{array}$ \\
\hline $\begin{array}{l}\text { School is in a } \\
\text { Metro } \times \text { Female }\end{array}$ & & & & & & $\begin{array}{c}-14.44^{*} \\
{[7.46]}\end{array}$ \\
\hline GGI & & & $\begin{array}{l}100.54 * \\
{[54.50]}\end{array}$ & & & \\
\hline GDP & & & $\begin{array}{c}3.66 \\
{[3.26]}\end{array}$ & & & \\
\hline Year FE & Yes & Yes & Yes & Yes & Yes & Yes \\
\hline Ancestry country FE & Yes & Yes & No & Yes & Yes & Yes \\
\hline Host country FE & Yes & Yes & Yes & Yes & Yes & Yes \\
\hline Host country FE $\times$ fem. & Yes & Yes & Yes & Yes & Yes & Yes \\
\hline $\begin{array}{l}\text { Observations } \\
R^{2}\end{array}$ & $\begin{array}{c}11,527 \\
0.35\end{array}$ & $\begin{array}{c}11,527 \\
0.35\end{array}$ & $\begin{array}{c}11,527 \\
0.28\end{array}$ & $\begin{array}{c}11,527 \\
0.38\end{array}$ & $\begin{array}{c}11,527 \\
0.40\end{array}$ & $\begin{array}{c}11,527 \\
0.40\end{array}$ \\
\hline
\end{tabular}

Notes: Results from estimating equation (1) on individuals' math scores. In all cases we use the five plausible values of math test scores provided by PISA datasets and report the average coefficient (Stata command pv). Following OECD recommendations, standard errors are adjusted following the Fay's BRR methodology using the 80 alternative weights provided by the PISA datasets. This takes into account PISA's stratified, two-stage sample design.

*** Significant at the 1 percent level. ** Significant at the 5 percent level. * Significant at the 10 percent level. 
(and the host-country fixed effects) is replaced by the country-of-residence GGI. Identification in this model comes from the variation of the level of gender equality across countries of residence, and thus captures both the effect of culture, as well as other institutional factors affecting the math gender gap in the country of residence. We are thus providing a lower bound of the effect of culture on the math gender gap.

Estimates from this alternative identification strategy show that a one standard deviation increase in the level of the gender equality index in the country of residence is associated with a 42 percent reduction in the standard deviation of the math gender gap. Comparing both estimates suggests that the transmission of cultural beliefs on the role of women in society accounts for at least two-thirds $(29 / 42=0.69)$ of the overall contribution of gender related factors to the math gender gap.

Our findings suggest that policies attempting to change cultural beliefs on the role of women in society may prove decisive in reducing the math gender gap. Future research ought to investigate whether the mechanism behind the effect of culture on the math gender gap is limited to math-specific gender stereotypes. Using evidence from the type of beliefs being transmitted, reading scores, and self-reported beliefs in math, Nollenberger, Rodríguez-Planas, and Sevilla (2015) find that this is not the case, suggesting that stereotypes against women more generally are also important.

\section{REFERENCES}

Dee, Thomas S. 2005. “A Teacher Like Me: Does Race, Ethnicity, or Gender Matter?" American Economic Review 95 (2): 158-65.

Fernández, Raquel. 2011. "Does Culture Matter?" In Handbook of Social Economics, Vol. $1 \mathrm{~B}$, edited by Jess Benhabib, Matthew O. Jackson, and Alberto Bisin, 481-510. Amsterdam: North-Holland

Fryer, Ronald, and Steven Levitt. 2010. "An Empirical Analysis of the Gender Gap in Mathematics." American Economic Journal: Applied Economics 2 (2): 210-40.

Gneezy, Uri, Muriel Niederle, and Aldo Rustichini. 2003. "Performance in Competitive Environments: Gender Differences." Quarterly Journal of Economics 118 (3): 1049-74.

Guiso, Luigi, Ferdinando Monte, Paola Sapienza, and Luigi Zingales. 2008. "Culture, Gender, and Math." Science 320: 1164-65.

Nollenberger, Natalia, Núria Rodríguez-Planas, and Almudena Sevilla. 2015. "The Math Gender Gap: A Tale of Culture and Institutions." Unpublished.

Pope, Devin G., and Justin R. Sydnor. 2010. "Geographic Variation in the Gender Differences in Test Scores." Journal of Economic Perspectives 24 (2): 95-108. 